\title{
Coalition trading in Spain: Explaining state-wide parties' government formation strategies at the regional level
}

\author{
Albert Falcó-Gimeno \\ Department of Constitutional Law and Political Science \\ University of Barcelona \\ afalcogimeno@ub.edu \\ Tània Verge \\ Department of Political and Social Sciences \\ Universitat Pompeu Fabra \\ tania.verge@upf.edu
}

This is an Accepted Manuscript of an article published by Taylor \& Francis in Regional \& Federal Studies 23(4): 387-405 in 2012, available online:

http://www.tandfonline.com/doi/10.1080/13597566.2012.758115

\begin{abstract}
In compounded polities, political parties need to coordinate their governing strategies across the central and the regional tiers of government. The coalition game is also more complex in these contexts, especially for the state-wide parties (SWP) that alternate in central office, as their need for cohesiveness across party levels is higher and the quest for vertical congruence across institutional levels is more pressing. This article aims at identifying the influence of the SWP situation at the central level on their government formation strategies at the regional level. By examining the Spanish case, we show that multi-level dynamics provide parties with incentives to trade government formation strategies at different levels. Particularly, when the SWP in the central government has a minority status, parliamentary support is more likely to be given to the investiture of non-state-wide parties (NSWP) in those regions where the latter are stronger.

Furthermore, we observe that, as political decentralization advanced, SWP seem to have been more inclined to adopt a cooperative behaviour toward NSWP. Overall, our findings suggest that SWP's strategies are not simply interconnected across levels but rather regional government formation decisions are hierarchically subject to centrallevel considerations.
\end{abstract}

\section{Keywords}

Decentralization; Political parties; Regional coalitions; Spain 


\section{Introduction}

The bulk of the literature on coalitions has traditionally focused on national governments. So far, very few studies have shifted their attention to the regional level (notable exceptions include Bäck, 2004; Colomer and Martínez, 1995; Downs, 1998; Hough and Verge, 2009; Reniu, 2005; Ştefuriuc, 2007, 2009a, 2009b; Rodríguez Teruel et al., 2010). Interestingly, the regional level provides researchers with the opportunity to examine coalition formation within a single country while counting with a relatively large number of cases. Regional-level approaches also allow controlling for a range of systemic factors identified by the literature (Laver, 1989).

Beyond instrumental reasons, the study of coalitions at the regional level is relevant per se. Political competition at different levels has relevant implications for party organization and party strategies (Roller and van Houten, 2003; Deschouwer, 2003; Detterbeck and Hepburn, 2010), such as the coordination of action across layers of government, basically between the central and the regional arenas (Hopkin, 2003). Specifically, operating simultaneously in different party systems (state-wide and regional) may force parties to reach agreements with diverse partners from different negotiating positions (Däubler and Debus, 2009).

Political parties might also pursue different goals at different levels (Downs, 1998). The study of coalitions in multi-level contexts allows distinguishing party goals according to their territorial pervasiveness (Reniu, 2011: 119), namely between statewide and non-state-wide parties (SWP and NSWP henceforth, respectively). SWP compete in all districts in all elections and exercise a crucial linkage function between levels of government whereas NSWP contest regional and/or politywide elections in one or few regions (Fabre, 2011: 345). Hence, the coalition game is potentially more complex for the former, especially for the largest SWP. Typically, they are governing 
parties at the central level, which makes more pressing their need for cohesiveness across party levels and the quest for vertical congruence across institutional arenas. In these contexts, coalition formation processes have been defined as "nested games" given that governing strategies at the central and regional levels are interconnected (Ştefuriuc, 2007).

This article builds on this emerging sub-field of research on coalitions by examining Spanish SWP's government formation strategies at the regional level from the early 1980s to 2011, comprising both the first and the most recent regional elections. In general, studies analysing government formation processes at the regional arena have focused on explaining the frequency of minority governments (Hamann and Mershon, 2008), and the congruence across the central and the regional levels (Ştefuriuc, 2007, 2009a). In contrast to previous research, we here follow the idea first posed by Colomer and Martínez (1995) who developed a model where parties could exchange their votes in different parliaments and reach inter-party agreements in several arenas simultaneously. This notion of "coalition trading" is based on the idea that a certain circumstance at one level will affect the coalitional strategy pursued by the party at the other level. We claim, however, that SWP's strategies are not simply interconnected across tiers but rather regional government formation decisions are hierarchically subject to central-level considerations. Hence, instead of analysing pacts in multiple arenas at the same time, this article aims at identifying the central level conditions under which parties are more likely to follow certain government formation strategies at the regional level.

In doing so, the article primarily concentrates on the two main Spanish SWP, namely the Spanish Socialist Workers' Party (Partido Socialista Obrero Español, PSOE) and the Popular Party (Partido Popular, PP) as well as its predecessor party 
Popular Alliance (Alianza Popular, AP). More concretely, we seek to identify how the SWP's position at the central level, will condition their behaviour at the regional level: whether they will prefer to govern alone, stay in opposition, or reach some kind of agreement with NSWP in the form of a coalition cabinet or an opposition-government collaboration.

The remainder of the article is structured as follows. The second section briefly introduces Spanish regional governments and SWP's participation in them. The third section specifies our hypotheses while the fourth describes the data and methods which drive the empirical analysis. The fifth section discusses the main findings in the light of our hypotheses. The final section highlights the contribution of the article and sets an agenda for further research.

\section{State-wide parties and regional governments in Spain}

As Detterbeck and Hepburn (2010: 124) remind us, "parties are struggling as much with the implications of state structural change resulting from multi-level governance in their internal organization, as they are externally in their responses to new divisions of state powers". State decentralization processes impact on the most relevant dimensions of party organization, namely distributional conflicts over resources, the definition of

platforms, and electoral and governing strategies (Downs, 1998; Chhibber and Kollman, 2004). As Ştefuriuc (2007: 45) argues “[the territorialisation of electoral competition] requires parties to adapt to a dual logic, as the governing and opposition experiences might overlap in time across levels, and so might the governing-alone and the governing-in-coalition experiences”.

In this sense, the Spanish case is particularly interesting for various reasons. On the one hand, regional governments hold significant power and have their own 
representative institutions. The governing resources and political visibility of the Spanish regions, the so-called Autonomous Communities (Comunidades Autónomas), have progressively expanded as decentralization advanced and, thus, have become crucial arenas for determining and implementing policy (Heller, 2002; Swenden and Maddens, 2009). On the other hand, the co-existence of the centre-periphery cleavage with the ideological left-right axis in some but not all regions has generated significant heterogeneity across the seventeen regional party systems (see Wilson 2012) with significant consequences for government formation. Although regional elections have been classified as second-order elections (Reiff and Schmitt, 1980; Jeffrey and Hough, 2003), the dissimilarity of electoral outcomes and the potential (vertical) incongruence of government composition across levels adds intricacy to policy making (Hamann and Mershon, 2008; Pallarés and Keating, 2003).

This article concentrates on state-wide parties (SWP), particularly on those which have governing capacity at the central level. SWP compete in all elections and regions throughout the territory and exercise a crucial linkage function between levels of government (Fabre, 2011: 345). Since 1982, only two Spanish SWP have alternated in central government. The PSOE governed from 1982 until 1996 (1993-96 minority government) and between 2004 and 2011 (in a minority status again), and the PP between 1996 and 2008 (2004-08 minority government) and from 2011 onwards. Indeed, these two parties account altogether for over 80 per cent of the seats of the lower house. Additionally, the PSOE and the PP are the main parties in most regions and their combined vote share at the regional level has significantly increased over time, nowadays reaching almost 80 per cent (Wilson, 2012: 128).

Figure 1 shows the evolution of the regional power hold by the PSOE and the PP. As it can be seen, PSOE's predominance was overturn by the PP in 1995. From 
1999 until 2011 regional power became much balanced between the main SWPs, with the PSOE taking the lead between 2003 and 2011, when regional power leaned again toward the PP. As of July 2011 the conservatives participated in eleven regional cabinets whereas the PSOE did so in just four - two single-party governments (Andalusia and the Basque Country) and two coalitions in which the Socialists were actually the junior partner and did not hold the premiership (Canary Islands and Navarre).

\section{[FIGURE 1 ABOUT HERE]}

Throughout the 1980-2011 period both SWP have been dependent on the support of NSWP at the central level and, at the same time, there have been numerous coalitional agreements between SWP and NSWP in the government of several regions. As it can be seen in Table 1, from 1980 up to July 2011, 30 per cent of all regional governments have been coalition governments, either in a minority or a majority status. In 47 out of 55 occasions a SWP was included in the coalition formula (85 per cent). Most often, regional coalition cabinets have been composed of a SWP and one or more NSWP (generally one). Interestingly, these governing coalitions very frequently reciprocate support at the central level, where the NSWP provides parliamentary support to the SWP in the Spanish parliament (see Ştefuriuc, 2009a and Barrio et al., 2010).

\section{[TABLE 1 ABOUT HERE]}

Given that SWP-NSWP coalitions have been more frequent for the PSOE than for the PP (Rodríguez Teruel et al., 2010), we might be inclined to think this is probably due to the fact that the PSOE is closer to the median and/or core position than the PP. Nonetheless, Figure 2 shows that when the two main dimensions of political competition are considered (left-right and centralization-decentralization), no clear 
pattern prevails. A large number of NSWP are either equidistant to both the PSOE and the PP or they are closer to the PSOE on one dimension but closer to the PP on the other. In any case, at the regional level, the PP has also reached numerous coalitional agreements with NSWP, either through the participation in a coalition government or through the support to the investiture of a NSWP single-party cabinet.

\section{[FIGURE 2 ABOUT HERE]}

\section{Theory and hypotheses}

As Ştefuriuc (2009a: 93-4) argues, “decentralized systems come by default with a need to coordinate party action across levels of governance $[\ldots]$. In such settings, political parties operate simultaneously in different party systems, hold different weights therein and need to strike deals with possibly different partners at different levels". In the same vein, Colomer and Martínez (1995) argue that several parties can agree on simultaneously exchange their votes in a set of parliaments and, acting rationally in their own self-interest, they can reach coalitional agreements that are apparently paradoxical. This multi-level game is particularly interesting for SWP whose access to a larger set of payoffs means that the losses at one level can be compensated with benefits at the other. As argued by Ştefuriuc (2009a: 98), for instance, SWP are also those more interested in stepping into congruent coalitions. Vertical congruence refers to the situation in which the party composition of a regional government coincides with that of the central government. SWP will highly value vertical congruence across institutional levels as a means to smooth intergovernmental relations on key policy issues thereby ensuring that regional governments have a fluid relationship with the central executive (Ştefuriuc, 2009a: 98). 
In this article we will focus on the central-regional linkages which work as determinants for SWP's government formation strategies at the regional level using Spain as a case study, one of the most decentralized countries in Western Europe. In particular, we seek to examine the influence of the SWP situation at the central level of government on their choice to strike coalition deals with other allies, basically NSWP, either forming a coalition cabinet or supporting the investiture of a regional prime minister without participating in government.

To study the determinants of SWP's regional government formation strategies, we first need to think about these parties' incentives. It is widely agreed that political parties value office, policy and votes, but different parties might assign a different priority to each of these goals (Strøm, 1990a) and some situations may entail trade-offs between them (Müller and Strøm 1999). Likewise, in multi-level polities parties might simultaneously pursue different goals at different levels (Downs 1998). Along these lines, Reniu (2011: 119) argues that SWP and NSWP have different sets of incentives to choose their strategies in the multi-level game of government formation. Access and survival in the central government is an intrinsic goal for SWPs as the polity-wide level is, in Deschouwer's (2003: 217) terms, their “core level of reference”. Regional government, then, becomes an instrumental goal for SWPs, but the opposite is true for NSWP -for which the regional level is their "core level of reference" (see also Ştefuriuc, 2009b: 100-101). Assuming that (at least the largest) SWP are officemaximisers and that they will prioritize survival in office in the central government, we claim that the behaviour of the party at the regional level will be hierarchically subject to its needs at the central level. In other words, when the position of a SWP at the central level is weak enough to depend on the votes of other parties to gain the investiture, pass policies, and/or survive until the next election, then the party's 
strategies for regional government formation will consider such a situation by engaging in a pattern of vote-exchange across levels.

Hitherto, only single-party governments have formed in the Spanish central level, although majority and minority governments have alternated. In fact, since democratization, the proportion of single-party minority governments has been above 50 per cent. These types of governments have relied on the support of other parties in the Congress of Deputies, very often through stable agreements. On these occasions, stable agreements with parliamentary supporting parties are equivalent to camouflaged or informal governing coalitions (Strøm, 1990b; for an analysis of the Spanish case, see Ştefuriuc, 2009b). Following the argument above, we expect SWP's strategies at the regional level to be strongly conditioned by the central level when they lead a singleparty minority government and need the support of other parties. So we go beyond what has been suggested by previous literature and argue that SWP will not be interested in congruence per se but instead they will engage in a vote-exchange pattern across levels to ensure the survival of the central government when they are in a minority situation there. In particular, we expect a more frequent use of cooperative strategies under these circumstances. Hence, our first hypothesis is the following:

Hypothesis 1: In minority situations at the central level, SWP will be more likely to pursue 'coalition' and 'supporting' strategies as opposed to 'singleparty' and 'opposition' ones at the regional level.

Although the above hypothesis may apply to SWP's general strategies at the regional level, the asymmetrical elements of the Spanish political system lead us to think that notable differences across regions will exist (see Ştefuriuc, 2009a: 99-100). Apart from asymmetry in their levels of fiscal autonomy and differences in their 
constitutional tracks to autonomy (fast-track versus slow-track regions), regions do also diverge with regard to the strength of their NSWP (Wilson, 2012). Besides the larger SWP (the PSOE, the PP, and the smaller United Left/Izquierda Unida, IU), three NSWP have traditionally been well represented in the lower chamber of the Spanish Parliament (Congreso de los Diputados): the Basque Nationalist Party (PNV, from the Basque Country), Convergence and Union (CiU, from Catalonia), and Canary Coalition (CC, from Canary Islands) and, more recently, Republican Left of Catalonia (ERC, from Catalonia). These parties are sometimes pivotal for the formation of a parliamentary majority at the central level (Barrio et al., 2010). Other NSWP, although pretty strong in their respective regional parliaments, are small and infrequently represented in the Spanish lower house. ${ }^{1}$ Given the regional differences on the potential influence of NSWP at the central level, we qualify the first hypothesis and state our second one:

Hypothesis 2: A minority situation at the central level will make SWP more likely to pursue 'coalition' and 'supporting' strategies as opposed to 'singleparty' and 'opposition' ones at the regional level, especially in those regions where NSWP are stronger.

Although we acknowledge that coalition formation is, at least, a two-party game, NSWP's preferences will not be considered in our framework. Obviously, we cannot assume that NSWP will always be ready to craft a coalition or a pact for the whole legislative term when approached by a given SWP. However, as long as NSWP are intrinsically interested in access to regional government, we assume that they will accept an agreement with the SWP that offers the most. It is true that the distance between NSWP and the SWP on the main axis of competition will strongly affect the 
decision taken by the former. However, in the Spanish case, it is very seldom the case that the NSWP is closer to one of the two SWP in both the ideological and territorial dimensions of political competition, as it has been shown in Figure 2. Hence, the fact that most NSWP are equidistant to both SWP will make them willing to accept the proposal of the highest bidder. In other words, the agreement will be closed with the party that demands less (for a demand-based model of policy compromises between parties see Morelli 1999). Our argument is that the "bid" of the SWP is more likely to be highest when it finds itself in a situation of minority in the central level and depends on the support of NSWP. As a result, they will behave more cooperatively, either offering the NSWP good conditions to form a coalition government or will demand little to offer their support for the investiture of a NSWP's regional prime minister.

The degree of political decentralization might also affect the types of agreements that parties reach at the regional level. ${ }^{2}$ It is reasonable to think that the higher relevance of regional executives in the design and implementation of policies will increase SWP's incentives to control or participate in more regional cabinets, either to coordinate the central government policies across the country or to confront the other SWP that leads the central government. In addition, political decentralization tends to consolidate the presence of NSWP at the regional electoral arena (De Winter et al., 2006) thereby expanding the opportunities for vote-exchanges between parties. Although regions do not hold a collective veto power within Spain's institutional framework and play a relatively minor role in the policy-making process at the central level (Aja, 2003), horizontal mechanisms among regional governments and intergovernmental bodies have expanded over time. In particular, the larger and the more substantive sharedcompetences are, the more vertical congruence will matter for SWP (Ştefuriuc, 2009a: 98). In sum, SWP might increasingly seek regional office as a means to coordinate the 
design and implementation of policies while in central government or as a means to coordinate opposition strategies to the central government otherwise. Hence, in our final hypothesis we expect that:

Hypothesis 3: SWP's choice for cooperative strategies will become more frequent as political decentralization advances.

\section{Data and Methods}

The universe of our empirical analysis is Spanish post-electoral regional governments from 1980 to 2011. However, departing from conventional practice in comparative research of national governments, we consider only those cabinets formed immediately after new elections. Despite some cabinet formations of Spanish regional executives have occurred during the term (i.e. inter-election formations), most of them are due to rather unclear changes in the party affiliation or parliamentary group membership of concrete legislators. As a consequence, the distribution of seats and bargaining power between parties in parliament does also change and, therefore, new majorities have to sustain new governments. Apart from the difficulty to identify these sometimes cumbersome changes of legislators' affiliation/membership, inter-election formations have the disadvantage that they are, by definition, highly dependent on the post-election formation that preceded them. We are here interested in studying SWP's regional formation strategies depending on their situation at the central level when the range of choices is not restricted, by construction, by previous formations. This is why we have only included post-election formations in our analyses, which are in fact the great majority of government formations.

Also, under those situations in which a party obtained the absolute majority of seats in parliament, one might intuitively think that 'single-party' or 'opposition' were 
the predominant if not unique courses of action. Although it is still possible for majority parties to build oversized coalitions or to receive the support of other SWP in the investiture vote, these situations are very rare in the Spanish regions. The two main SWP have never joined an oversized coalition and the support strategy to a governing party that already had the absolute majority of votes in parliament has been only chosen three times. ${ }^{3}$ Given the extremely low frequency of these situations and the irrelevance of the investiture vote in these cases, the empirical analysis concentrates on those cases in which no party obtained a majority of seats after elections, which are substantively far more interesting. In fact, it is in these situations when SWP's strategies (namely, our dependent variable) are really relevant.

Applying these criteria, and excluding the few SWP-SWP agreements, ${ }^{4}$ the number of government formation opportunities we analyse is 69 . However, since we are interested in evaluating SWP's strategic choices in each regional government formation opportunity, we create two observations for each: one for the PSOE and one for the PP. Both parties decide at the same time what strategy to pursue and even negotiate concurrently with the same potential partners in order to obtain their support for a single-party cabinet, for a coalition, or to engage in a vote-exchange process across institutional levels, and this is precisely what we want to study. Hence, the number of observations expands to 137, 69 for the PSOE and 68 for the PP -the difference obeying to the fact that the PP did not obtain parliamentary representation in the Catalan elections of 1980 and, therefore, did not have any strategic choice available.

Following Hamann and Mershon (2008: 118), we define our units of analysis, political parties, as "recognizable teams". If a group of politicians, even if they formally belong to separate parties, contest elections under the same label we treat them as a single party. This applies to the Catalan nationalist NSWP CiU as well as the electoral 
coalitions the PP participated in during the 1980s and early 1990s (such as Coalición Popular or Coalición Democrática). Different parties are also considered as one organization if they regularly constitute a single parliamentary group. This is the case of the Party of the Catalan Socialists (Partit dels Socialistes de Catalunya, PSC), which organizationally substitutes for the PSOE in Catalonia, and of the Navarrese People's Union (Unión del Pueblo Navarro, UPN), which has done so for the PP in Navarre for several years (see Verge and Barberà, 2009). For the purposes of the empirical analyses, although formally independent parties, the PSC and the UPN are considered part of the PSOE and the PP organizations, respectively, given that they do not compete against each other and they do not form separate parliamentary groups. ${ }^{5}$

It is also important to mention that, all throughout the paper, we understand SWP's regional coalition strategies as if decided by the central party leadership. Given that multi-level electoral politics introduces centrifugal pressures on SWP (see Hough and Jeffrey, 2006), we can imagine a situation in which a regional branch strikes a coalition deal while the central party opposes it. Nonetheless, the two main Spanish SWP are significantly vertically integrated (Fabre, 2011; Thorlakson, 2009, 2011). Whereas political decentralization has clearly shaped parties' electoral and executive strategies, their internal decentralization has remained quite modest (Fabre and MéndezLago, 2009; Hopkin, 2009). This is why the central level clearly prevails when it comes to government formation strategies. To the best of our knowledge, in the past thirty years, there have been very few cases in which the central party has de-authorized the coalition agreement reached by a regional party branch, which seems to imply that regional governing strategies are either decided at the central level or at least consensually agreed between party levels. ${ }^{6}$ 


\section{Dependent variable}

Our main dependent variable is SWP's government formation strategy at the regional level. Following regional elections, SWP have various options or strategies at their disposal. As described in Table 2, we have created a nominal variable with four categories, namely single-party, coalition with a NSWP, supporting party (to a NSWP), and opposition, which correspond to the strategies available to SWP.

\section{[TABLE 2 ABOUT HERE]}

The supporting-party role is defined as the SWP voting in favour or abstaining in the investiture of a regional government that does not include itself. Even if voting 'aye' sends a stronger signal of support, abstaining typically allows the investiture of a regional prime minister and her government. This is why we consider abstention in the investiture vote as a 'supporting strategy'. We admit that a truly supporting attitude towards the government from the opposition benches arguably entails more than casting a vote on the single occasion of the investiture. However, the analysis of the complete voting pattern in parliament for three decades would require regional parliamentary voting records that are frequently unavailable. Moreover, our dependent variable refers to government formation strategies rather than SWP's behaviour during the term. Therefore, we have opted for the investiture vote as a highly symbolic gesture reflecting the (un)cooperative intentions of the SWP toward the newly invested government. It bears mentioning that we have also considered as an 'opposition' strategy those abstentions cast in those few regional parliaments where it is not possible to openly vote against the investiture of a candidate as in these case abstention is equivalent to a negative vote. 


\section{Independent variables}

As stated in the hypotheses, our main purpose is to identify to what extent multi-level dynamics matter for SWP's strategies in regional government formation. More specifically, we seek to gauge whether or not the course of action Spanish SWP decide to take in different regions at the time to form a (post-election) government is hierarchically subject to the situation of the SWP at the central level (namely, in the Spanish parliament and, subsequently, in the Spanish government). ${ }^{7}$ As a result, our independent variables are the following:

- Central Government (CG): This is a categorical variable with three values distinguishing whether i) the SWP controls the majority of seats at the central level, whether ii) it governs in a minority situation, or rather, iii) it remains in opposition, the latter being the reference category.

- \% Seats NSWP: This variable measures the percentage of seats obtained by the largest NSWP in each region. It is also interacted with the SWP's status at the central government.

- Regional Authority Index: We use the index created by Hooghe et al. (2010) which captures the level of authority of regional entities in decentralized countries on an annual basis. This index measures both the self-rule and sharedrule dimensions of political decentralization. Data is available for the Spanish Autonomous Communities for the period 1978-2006. As a result, we lose some observations in those analyses where this variable is included, specifically the 2007 and 2011 post-electoral government formations.

- Party: This dummy identifies the SWP party in the analyses (' 1 ' for the PP and ' 0 ' for the PSOE). Hence, the specified statistical models are party fixed-effect regressions. 
- Days to general elections: We include as a control variable the time left to the next general elections, measured in days, taking as a benchmark the last regional elections which produced the new (post-election) government. The influence of the situation of the SWP in central government on how it will behave in the regional government might be considerably conditioned by how long the central government is expected to last. Electoral cycles are crucial as the timing of elections at the different levels forces parties to introduce different time horizons simultaneously in their calculations (see Deschouwer, 2009; Däubler and Debus, 2009). As a result, when regional elections are close to the upcoming general elections, SWP might use government formation at the regional level as a "testing ground" for vertical congruence at the polity-wide level (Ştefuriuc, 2009c: 6).

Given the categorical nature of our dependent variable, we run multinomial logistic regressions where the strategy 'opposition' is specified as the reference category. Since we have two observations for each post-election government formation and the strategies of both the PSOE and the PP are likely to be closely linked, we have specified government-clustered standard errors. ${ }^{8}$

\section{Discussion of findings}

According to our first hypothesis, we expect that SWP's situation at the central level will affect their government formation strategies at the regional level. We have argued that their behaviour will tend to be more cooperative when the SWP leads the central government in a minority situation in parliament. Table 3 shows that, in the absence of other control variables, the strategies of 'coalition' and 'support' are less likely when 
the SWP runs a majority government at the central level, although only the latter is statistically significant at a 99 per cent confidence level. Simultaneously, under this situation, SWP seem to be more prone to form single-party governments at the regional level. These first findings are tentatively consistent with the first hypothesis.

Nevertheless, under minority situations at the central government, our first analysis does not reveal any relevant effect: the three displayed strategies of the dependent variable seem to be more likely than the reference category (an overtly opposition strategy), but the estimations are far from statistical significance.

\section{[TABLE 3 ABOUT HERE]}

Yet, when the regional dimension is incorporated into the analysis through the variables size of the NSWP (\% Seats NSWP) and number of days left to the next general elections the results substantially change. In Table 4 we can see that the interaction between the minority situation of the SWP at the central level and the percentage of seats of the main NSWP in a given region has a positive sign and reaches standard levels of statistical significance for the strategy 'support' (model 2). This finding is congruent with hypothesis 2 . Indeed, under minority situations, SWP seem to be more likely to adopt cooperative strategies at the regional level ('support', in particular), most clearly where NSWP are stronger. Although the variable days to general election never reaches the significance level, the coefficient is consistently negative for the 'coalition' and 'support' strategies, showing that the greater the time remaining for the next general election the less cooperative SWP will behave. To put it differently, SWP will be interested in sending a signal of cooperation to NSWP in the region the closer the elections at the central level are in order to secure their support and form congruent coalitions across levels.

[TABLE 4 ABOUT HERE] 
Figure 3 shows a linear fit simulation of the predicted probability of the 'support' strategy as the size of the main NSWP in the region increases, for two different situations of the SWP at the central government. In those regions where NSWPs are weak, the probability of adopting a 'support' strategy toward them is logically 0 , irrespective of the SWP having a minority status at the central government. However, the multi-level effect clearly emerges where NSWPs are stronger. In these regions, SWPs are much more likely to support the investiture of the candidate of a NSWP when they are in a minority status at the central government than in other situations.

\section{[FIGURE 3 ABOUT HERE]}

Models 3 and 4 incorporate the Regional Authority Index (RAI) in the regressions. As mentioned earlier, the RAI is only available until 2006, which forces us to work with a sub-sample of the longitudinal data used until now. Interestingly, the inclusion of the RAI reveals that, as political decentralization advanced, the 'support' strategy became more likely. This finding is consistent to our third hypothesis: the increasing relevance of regions in the political landscape of Spain seems to have pushed SWP to be more cooperative at the regional level when it comes the time to form a government. Finally, we should also mention that some statistical differences emerge comparing the behaviour of the two main SWP. All else being equal, the PP seems to have been slightly more inclined to adopt cooperative strategies, while it has been less prone (or less able) to govern alone in the regions. The main intention behind the inclusion of this dummy was, however, to control for potential partisan "fixed-effects". These differences do certainly deserve further qualitative insight but they fall beyond the scope of our analysis. In sum, we have provided evidence for the influence of the 
central level situation of SWP on their regional government formation strategies, controlling for the specific party we look at.

\section{Concluding remarks}

In Western Europe, the regional tier of government has acquired increasing authority and visibility in past decades. Apart from the implications it has had for party organization, government formation in multi-level polities has required parties to coordinate their governing action across levels. This need has been especially pressing for SWP, as their governing and opposition experiences overlap in time across levels. Therefore, the analysis of the central-regional linkages in government formation processes requires special attention. This article takes a step forward in this direction. We have focused on SWP's government formation strategies at the regional level in order to disentangle under what conditions SWP will prefer to pact with NSWP.

Our initial expectation was that minority situations at the central government should lead SWP to adopt more cooperative strategies at the regional level in order to secure the support of other parties, namely NSWP, at the central level. This hypothesis has been to a great extent confirmed by the empirical analysis, although only for regions where NSWP have a significant weight. For arithmetic reasons, this is not particularly surprising as we should expect SWP to close agreements with NSWP precisely in those regions where the latter are important political actors. Yet, our results also show that in these regions SWP opt for cooperative strategies (outside parliamentary support, mainly) when they have a minority status at the central government much more frequently than in any other situation. Therefore, our empirical analysis of regional government formation processes in Spain for the entire democratic period (1980-2011) seems to reveal that multi-level dynamics do matter to understand the strategies that 
SWP adopt when regional elections have been held and a new government has to be formed. Finally, the empirical analysis has also revealed a dynamic trend. SWP's strategies seem to have changed over time in response to the process of political decentralization. As the regional tier acquired more authority, SWP have become more likely to adopt cooperative strategies.

With a view to confirming the importance of the multi-level dynamics and identifying potential differences across parties as regards their strategies, future qualitative analyses could examine in greater detail the regional government strategies of the PSOE and the PP separately. In-depth investigation of the impact of political decentralization processes on parties' incentives and strategies at the regional level could also prove fruitful. Last, given their simplicity and generalisability, the hypotheses presented in this article can be easily applied to other decentralized countries where the multi-level context makes parties' governing and opposition experiences overlap across tiers of government. 


\section{Endnotes}

\footnotetext{
${ }^{1}$ In fact, they frequently participate in coalitions in their regions, such as the PAR (Aragon), CDN (Navarre), EA (Basque Country), and PRC (Cantabria), among others (see Reniu, 2005 and Rodríguez Teruel et al., 2010). Amaiur (Basque Country) will merit especial attention in future regional elections.
}

${ }^{3}$ The PP supported the investiture of former regional prime minister Jordi Pujol in Catalonia in 1984 (positive vote), and in 1988 and 1992 (abstention) despite the NSWP CiU had the absolute majority of seats.

${ }^{4}$ Apart from SWP-NSWP regional agreements, some pacts have only involved two SWP. Yet, during the whole period under study, SWP-SWP coalitions have only taken place three times, one in Castile Leon (1989-1991) between the PP and the Centro Democrático y Social (CDS), and twice in Asturias between the PSOE and the left-wing United Left (Izquierda Unida, IU) (2003-2007 and 2008-2011; for an analysis of the participation of IU in regional coalition governments see Ştefuriuc and Verge (2008)). Also, in the Balearic Islands, the coalition governments led by the PSOE (1999-2003 and 2007-2011) had to include the IU along with various NSWP in order to secure the majority of seats. The cases of support or coalition between SWP occurred in the Basque Country in 2009 (the PP supported the investiture of the PSOE), and in Navarre in 1999 and 2007 (the PSOE supported the investiture of UPN which at that time was the organizational substitute of the PP in the region). Likewise, in 2003 the PSOE and IU formed a postelectoral coalition in Asturias. Since we focus on SWP's strategies vis-à-vis NSWP, we have decided not to include SWP-SWP agreements in any of the categories of the dependent variable and drop them from the analyses in order to reduce bias.

${ }^{5}$ As an exception to this general rule, the UPN and the PP are considered as different parties in the Navarrese regional elections of 1983, 1987, and 2011, since both parties then run in separate lists. 
${ }^{6}$ In 2007 PSOE's regional branch in Navarre was about to close a coalition agreement with several NSWP when negotiations were abruptly called off by the central party leadership (see Fabre 2008). Regarding IU, although we do not examine this party here, after the 2011 regional elections the Extremadura regional branch contravened the central party instructions to support the investiture of the PSOE candidate and supported instead the investiture of the PP candidate through an abstention.

${ }^{7}$ It is important to note that it is beyond the scope of this paper to adopt an integral approach to government formation in Spanish regional governments. There is certainly a greater number of variables at play to understand what types of government finally form. However, as already highlighted, in this article we are just interested in exploring how SWP's situation at the central level affects their government formation strategies at the regional level.

${ }^{8}$ We have run additional analyses including some control variables to capture the influence of certain institutional factors that may impact on the choice of the government strategies, such as the percentage of deputies needed to present a vote of no-confidence or the consequences of a failed investiture. However, since these variables did not influence the direction or the strength of the coefficients, they are not presented in the tables of results in favour of a more parsimonious specification of the models and a simpler presentation. 


\section{References}

Aja, Eliseo (2003), El Estado autonómico: federalismo y hechos diferenciales. Madrid: Alianza, $2^{\text {nd }}$ edition.

Bäck, Hanna (2003), Explaining coalitions: Evidence and lessons from studying coalition formation in Swedish local government. Uppsala: Acta Universitatis Upsaliensis.

Barrio, Astrid, Juan Rodríguez Teruel, Montserrat Baras, and Òscar Barberà (2010), "Partidos de ámbito no estatal y gobernabilidad multinivel: el caso de España (1977-2008)”. Working Papers number 291. Barcelona: Institut de Ciències Polítiques i Socials.

Centro de Investigaciones Sociológicas (2010), Barómetro autonómico (II), study number 2829. Madrid: CIS.

Chhibber, Pradeep and Ken Kollman (2004), The Formation of National Party Systems:

Federalism and Party Competition in Canada, Great Britain, India and the United States. Oxford: Princeton University Press.

Colino, César (2010), “Constitutional Change Without Constitutional Reform: Spanish Federalism and the Revision of Catalonia's Statute of Autonomy", Publius: The Journal of Federalism Vol. 39, No. 2, pp. 262--88.

Colomer, Josep M., and Florencio Martinez (1995), “The Paradox of Coalition Trading”, Journal of Theoretical Politics Vol. 7, No. 1, pp. 41--63.

Däubler, Thomas, and Marc Debus (2009), "Government Formation and Policy Formulation in the German States”, Regional and Federal Studies Vol. 19, No. 1, pp. 73--95.

De Winter, Lieven, Margarita Gómez-Reino, and Peter Lynch (2006), Autonomist Parties in Europe: Identity Politics and the Revival of the Territorial Cleavage. Barcelona: ICPS.

Deschouwer, Kris (2003), "Political Parties in Multi-layered Systems". European Urban and Regional Studies, Vol. 10, No. 3, pp. 213--26. 
Deschouwer, Kris (2009), “Coalition Formation and Congruence in a Multi-Layered Setting: Belgium 1995-2008”, Regional \& Federal Studies, Vol. 19, No. 1, pp. 13--35.

Detterbeck, Klaus and Eve Hepburn (2010), "Party politics in multi-level systems: Party esponses to new challenges in European democracies", in Jan Erk and Wilfried Swenden (eds), New directions in federalism studies. London: Routledge/ECPR, pp. 106--25.

Downs, William (1998), Coalition Government, Subnational Style: Multiparty Politics in Europe's Regional Parliaments. Columbus: Ohio State University Press.

Fabre, Elodie (2008), "Party Organization in a Multi-Level System: Party Organizational Change in Spain and the UK", Regional and Federal Studies, Vol. 18, No. 4, pp. 309--29.

Fabre, Elodie (2011), "Measuring party organization: The vertical dimension of the multi-level organization of state-wide parties in Spain and the UK", Party Politics, Vol. 17, No. 3, pp. 343--63.

Fabre, Elodie, and Mónica Méndez-Lago (2009), “Decentralization and Party Organizational Change: the British and Spanish Statewide Parties Compared", in Wilfried Swenden and Bart Maddens (eds), Territorial Party Politics in Western Europe. Basingstoke: Palgrave Macmillan, pp. 102--118.

Falcó-Gimeno, Albert (2012), “The Allocation of Regional Cabinet Ministries under Decentralization: The Case of Regional Coalition Governments in Spain (1980-2010)", paper prepared for presentation at the 2nd Annual General Conference of the European Political Science Association. Berlin, June 21-23, 2012.

Franklin, Mark N., and Thomas T. Mackie (1983), "Familiarity and inertia in the formation of governing coalitions in parliamentary democracies", British Journal of Political Science, Vol. 13, pp. 275--98. 
Hamann, Kerstin and Carol Mershon (2008), "Regional governments in Spain: Exploring Theories of Government formation", in Bonnie N. Field and Kerstin Hamann (eds), Democracy and Institutional Development: Spain in Comparative Theoretical Perspective. New York: Palgrave Macmillan, pp. 203--16.

Heller, William B. (2002), “Regional Parties and National Politics in Europe: Spain's Estado de las Autonomías, 1993 to 2000”, Comparative Political Studies, Vol. 35, No. 6, pp. 657--85. Hooghe, Liesbet, Gary Marks, and Arjan Schakel (2010), The Rise of Regional Authority: A Comparative Study of 42 Democracies. London: Routledge.

Hopkin, Jonathan (2003), "Political decentralization, electoral change and party organizational adaptation: A framework for analysis", European Urban and Regional Studies, Vol. 10, No. 3, pp. 227--37.

Hopkin, Jonathan (2009), "Party Matters: Devolution and Party Politics in Britain and Spain", Party Politics, Vol. 15, No. 2, pp. 179--98.

Hough, Dan, and Charles Jeffrey (2006), Devolution and electoral politics. Manchester: Manchester University Press.

Hough, Dan, and Tània Verge (2006), “A Sheep in Wolf”s Clothing or a Gift from Heaven? LeftLeft Coalitions in Comparative Perspective", Regional and Federal Studies, Vol. 19, No. 1, pp. 37--55.

Jeffery, Charlie, and Dan Hough (2003), "Regional Elections in Multi-Level Systems”. European Urban and Regional Studies, Vol. 10, No. 3, pp. 199--212.

Laver, Michael (1989), "Theories of coalition formation and local government coalitions", in Colin Mellors and Bert Pijnenburg (eds), Political parties and coalitions in European local government. London: Routledge, pp. 15--34. 
Laver, Michael, and Kenneth A. Shepsle (1996), Making and breaking governments: Cabinet and legislatures in parliamentary democracies. Cambridge: Cambridge University Press.

Molero, Juan C. (2001), “Analysis of the decentralization of public spending in Spain”, Public Finance and Management Vol. 1, pp. 500--56.

Morelli, Massimo (1999), "Demand Competition and Policy Compromise in Legislative Bargaining”, American Political Science Review, Vol. 93, No. 4, pp. 809--20.

Müller, Wolfgang C., and Kaare Strøm (1999), "Political parties and hard choices”, in Wolfgang C. Müller and Kaare Strøm (eds), Policy, Office, or Votes. How Political Parties in Western Europe Make Hard Decisions. New York: Cambridge University Press, pp. 1--35.

Pallarés, Francesc, and Michael Keating (2003), "Multi-level Electoral Competition: Regional Elections and Party Systems in Spain”, European Urban and Regional Studies Vol. 10, pp. 239--255.

Reniu, Josep M. (2005), “Multilevel government formation: An assessment on Spanish regional democracy". Paper presented at the ECPR Joint Sessions of Workshops, Granada, 14-19 April, 2005.

Reniu, Josep M. (2011), “'Spain is Different'. Explaining minority governments by diverging party goals", in Rudy W. Andeweg and Leiven de Winter (eds), Puzzles of government formation. Coalition theory and deviant cases. London: Routledge, pp. 112--28.

Reif, Karlheinz, and Hermann Schmitt (1980), "Nine Second-order National Elections: a Conceptual Framework for the Analysis of European Election Results", European Journal of Political Research, Vol. 8, No. 1, pp. 3--44.

Roller, Elisa, and Pieter Van Houten (2003), “A National Party in a Regional Party System: The PSC-PSOE in Catalonia", Regional and Federal Studies Vol. 13, No. 1, pp. 1--22. 
Rodríguez Teruel, Juan, Àstrid Barrio, Montserrat Baras, and Òscar Barberà (2010). “Las respuestas estratégicas de los partidos de ámbito estatal a los desafíos de la competición multinivel: la política de alianzas del PP y el PSOE en las Comunidades Autónomas de España (1980-2008)”. Working Papers number 284. Barcelona: Institut de Ciències Polítiques i Socials.

Ştefuriuc, Irina (2007), "The coalition strategies of state-wide parties in multi-level settings", in Kris Deschouwer and Theo M. Jans (eds), Politics beyond the State: Actors and Policies in Complex Institutional Settings. Brussels: Brussels University Press, pp. 45--70.

Ştefuriuc, Irina (2009a), “Government Formation in Multi-Level Settings: Spanish Regional Coalitions and the Quest for Vertical Congruence", Party Politics, Vol. 5, No. 1, pp. 93-115.

Ştefuriuc, Irina (2009b), "Explaining Government Formation in Multi-Level Settings: Coalition Theory Revisited - Evidence from the Spanish Case", Regional \& Federal Studies, Vol. 19, No. 1, pp. 97--116.

Ştefuriuc, Irina (2009c), "Introduction: Government Coalitions in Multi-Level Settings Institutional Determinants and Party Strategy", Regional \& Federal Studies, Vol. 19, No. 1, pp. 1--12.

Ştefuriuc, Irina, and Tània Verge (2008), "Small and Divided Parties in Multi-Level Settings: Opportunities for Government Participation, the Case of Izquierda Unida in Spain”, South European Society and Politics, Vol. 13, No. 2, pp. 155--173

Strøm, Kaare (1990a), “A behavioral theory of competitive political parties”, American Journal of Political Science, Vol. 34, No. 2, pp. 565--98.

Strøm, Kaare (1990b), Minority Government and Majority Rule. Cambridge: Cambridge University Press. 
Swenden, Wilfried, and Bart Maddens (2009), Territorial Party Politics in Western Europe. New York: Palgrave Macmillan.

Thorlakson, Lori (2009), "Patterns of Party Integration, Influence and Autonomy in Seven Federations", Party Politics, Vol. 15, No. 2, pp. 157--77.

Thorlakson, Lori (2011), "Measuring vertical integration in parties with multi-level systems data", Party Politics (DOI: 10.1177/1354068811411024, online first published on 29 July 2011).

Verge, Tània, and Òscar Barberà (2009), “Descentralización y estrategias organizativas: las relaciones especiales entre partidos de ámbito estatal (PAE) y partidos de ámbito no estatal (PANE) en España”. Working Papers number 281. Barcelona: Institut de Ciències Polítiques i Socials.

Warwick, Paul (1994), Government Survival in Parliamentary Democracies. Cambridge: Cambridge University Press.

Wilson, Alex (2012), "Multi-level Party Systems in Spain”, Regional \& Federal Studies, Vol. 22, No.2, pp. 123--139. 


\section{Tables and Figures}

Table 1. SWPs in regional governments, 1980-2011

\begin{tabular}{cccccc}
\hline \multirow{2}{*}{ Type of government } & \multicolumn{3}{c}{ SWPs in government } & \multirow{2}{*}{$\begin{array}{c}\text { No SWPs in } \\
\text { government }\end{array}$} & \multirow{2}{*}{ TOTAL } \\
\cline { 2 - 4 } & PSOE & PP & Other (CDS) & \\
\hline Single-party & $51(66 \%)$ & $59(76 \%)$ & 0 & $18(69 \%)$ & $128(70 \%)$ \\
Coalition & $26(34 \%)$ & $18(24 \%)$ & $3(100 \%)$ & $8(31 \%)$ & $55(30 \%)$ \\
\hline TOTAL & $77(100 \%)$ & $77(100 \%)$ & $3(100 \%)$ & $26(100 \%)$ & $183(100 \%)$ \\
\hline \hline
\end{tabular}

Source: Own elaboration, based on Ştefuriuc (2007) and updated by the authors.

Note: The table includes both post-electoral and inter-electoral governments. The majority/minority status is not distinguished here. Pre-autonomic governments are excluded. 
Table 2. SWPs' government formation strategy at the regional level

\begin{tabular}{cccc}
\hline \hline Single-party & Coalition & Supporting & Opposition \\
\hline $\begin{array}{c}\text { The SWP forms a } \\
\text { single-party } \\
\begin{array}{c}\text { government, including } \\
\text { no other partner. }\end{array}\end{array}$ & $\begin{array}{c}\text { The SWP forms a } \\
\text { cabinet with one or } \\
\text { various NSWPs. }\end{array}$ & $\begin{array}{c}\text { The SWP supports the } \\
\text { investiture of a NSWP } \\
\text { candidate, casting a } \\
\text { positive vote or } \\
\text { abstaining. }\end{array}$ & $\begin{array}{c}\text { The SWP votes } \\
\text { against the investiture } \\
\text { of another party's } \\
\text { regional PM. }\end{array}$ \\
\hline \hline
\end{tabular}


Table 3. Multinomial regression analysis: Basic model

\begin{tabular}{cccc}
\hline \hline & Single-party & Coalition & Support \\
\hline & & & \\
Majority at the central government (CG) & $1.166^{*}$ & -0.377 & $-14.614 * * *$ \\
& $(0.625)$ & $(0.666)$ & $(0.670)$ \\
Minority at the CG & 0.629 & 0.663 & 1.098 \\
& $(0.703)$ & $(0.589)$ & $(0.787)$ \\
Constant & $-1.658^{* * *}$ & $-0.904 * * *$ & $-2.639 * * *$ \\
& $(0.382)$ & $(0.291)$ & $(0.603)$ \\
& & & \\
\hline Observations & \multicolumn{3}{c}{137} \\
Pseudo- $\mathrm{R}^{2}$ & 0.043 \\
\hline \hline
\end{tabular}

Standard errors clustered by government in parenthesis.

$* * * \mathrm{p}<0.01 ; * * \mathrm{p}<0.05 ; * \mathrm{p}<0.1$. 
Table 4. Multinomial regression analysis: Full models

\begin{tabular}{|c|c|c|c|c|c|c|c|c|c|c|c|c|}
\hline & \multicolumn{3}{|c|}{ "Model (1) } & \multicolumn{3}{|c|}{ Model (2) } & \multicolumn{3}{|c|}{ Model (3) } & \multicolumn{3}{|c|}{ Model (4) } \\
\hline & Single-party & Coalition & Support & Single-party & Coalition & Support & Single-party & Coalition & Support & Single-party & Coalition & Support \\
\hline \multirow{2}{*}{$\begin{array}{l}\text { Majority at the } \\
\text { central government } \\
\text { (CG) }\end{array}$} & 0.907 & -0.569 & $-13.719 * * *$ & 0.587 & -1.572 & $-19.931 * * *$ & $1.254^{*}$ & -0.687 & $-15.286^{* * *}$ & 0.847 & -1.849 & $-18.573 * * *$ \\
\hline & $(0.585)$ & $(0.861)$ & $(0.928)$ & $(0.774)$ & $(1.351)$ & $(1.512)$ & $(0.714)$ & $(0.813)$ & $(0.960)$ & $(0.879)$ & (1.317) & $(1.720)$ \\
\hline \multirow{2}{*}{ Minority at the CG } & 0.471 & 0.200 & 1.093 & 0.520 & -0.657 & $-824.917 * * *$ & 0.833 & -0.170 & -0.079 & 0.590 & -1.655 & $-846.362 * * *$ \\
\hline & $(0.740)$ & $(0.720)$ & $(0.893)$ & $(0.916)$ & $(1.151)$ & $(40.255)$ & $(0.969)$ & $(0.794)$ & $(0.941)$ & (1.135) & (1.549) & $(41.152)$ \\
\hline \multirow{2}{*}{$\%$ Seats NSWP } & $-0.082 * * *$ & -0.006 & $0.172 *$ & $-0.083 * * *$ & -0.026 & $0.089 * *$ & $-0.079 * * *$ & -0.009 & $0.146 * * *$ & $-0.088 * * *$ & -0.039 & $0.111 * *$ \\
\hline & $(0.017)$ & $(0.010)$ & $(0.091)$ & $(0.024)$ & $(0.018)$ & $(0.039)$ & $(0.018)$ & $(0.012)$ & $(0.055)$ & $(0.029)$ & $(0.024)$ & $(0.050)$ \\
\hline \multirow{2}{*}{$\begin{array}{l}\text { Majority at the CG * } \\
\% \text { Seats NSWP }\end{array}$} & & & & 0.019 & 0.049 & $-0.095 * *$ & & & & 0.023 & 0.061 & $-0.112^{*}$ \\
\hline & & & & $(0.046)$ & $(0.044)$ & $(0.048)$ & & & & $(0.049)$ & $(0.047)$ & $(0.064)$ \\
\hline \multirow{2}{*}{$\begin{array}{l}\text { Minority at the CG * } \\
\% \text { Seats NSWP }\end{array}$} & & & & -0.040 & 0.043 & $20.274 * * *$ & & & & -0.004 & 0.072 & $20.766^{* * *}$ \\
\hline & & & & $(0.077)$ & $(0.039)$ & $(0.995)$ & & & & $(0.071)$ & $(0.053)$ & $(1.022)$ \\
\hline \multirow{2}{*}{$\begin{array}{l}\text { Days to general } \\
\text { elections }\end{array}$} & 0.000 & -0.001 & -0.003 & 0.000 & -0.001 & -0.002 & 0.000 & -0.001 & -0.005 & 0.000 & -0.001 & -0.004 \\
\hline & $(0.001)$ & $(0.001)$ & $(0.002)$ & $(0.001)$ & $(0.001)$ & $(0.002)$ & $(0.001)$ & $(0.001)$ & $(0.004)$ & $(0.001)$ & $(0.001)$ & $(0.003)$ \\
\hline \multirow{2}{*}{ Party (PP) } & -0.487 & -0.646 & 1.180 & -0.479 & -0.713 & $20.206^{* * *}$ & $-0.193 * *$ & $0.703 * *$ & -0.069 & $-0.185^{*}$ & $0.681 * *$ & 0.149 \\
\hline & $(0.558)$ & $(0.690)$ & $(0.831)$ & $(0.534)$ & $(0.685)$ & $(6.991)$ & $(0.094)$ & $(0.333)$ & $(0.275)$ & $(0.096)$ & $(0.337)$ & $(0.180)$ \\
\hline \multirow{2}{*}{$\begin{array}{l}\text { Regional Authority } \\
\text { Index }\end{array}$} & & & & & & & -0.363 & -0.535 & $2.179 * *$ & -0.415 & -0.607 & $21.641 * * *$ \\
\hline & & & & & & & $(0.637)$ & $(0.708)$ & $(1.031)$ & $(0.631)$ & $(0.719)$ & $(1.001)$ \\
\hline \multirow{2}{*}{ Constant } & -0.494 & 0.073 & $-7.999 * *$ & -0.396 & 0.512 & $-24.141 * * *$ & $3.161^{*}$ & $-14.957 * *$ & -4.465 & $3.213^{*}$ & $-13.829 *$ & $-27.664 * * *$ \\
\hline & $(0.584)$ & $(0.685)$ & $(3.255)$ & $(0.619)$ & $(0.771)$ & (0.994) & $(1.751)$ & $(7.388)$ & $(5.320)$ & (1.707) & $(7.427)$ & (3.797) \\
\hline Observations & & 137 & & & 137 & & & 113 & & & 113 & \\
\hline Pseudo- $\mathrm{R}^{2}$ & & 0.167 & & & 0.211 & & & 0.200 & & & 0.241 & \\
\hline
\end{tabular}

Standard errors clustered by government in parentheses.

*** $\mathrm{p}<0.01 ; * * \mathrm{p}<0.05 ; * \mathrm{p}<0.1$. 
Figure 1. SWPs' presence in regional governments, 1980-2011 (numbers)

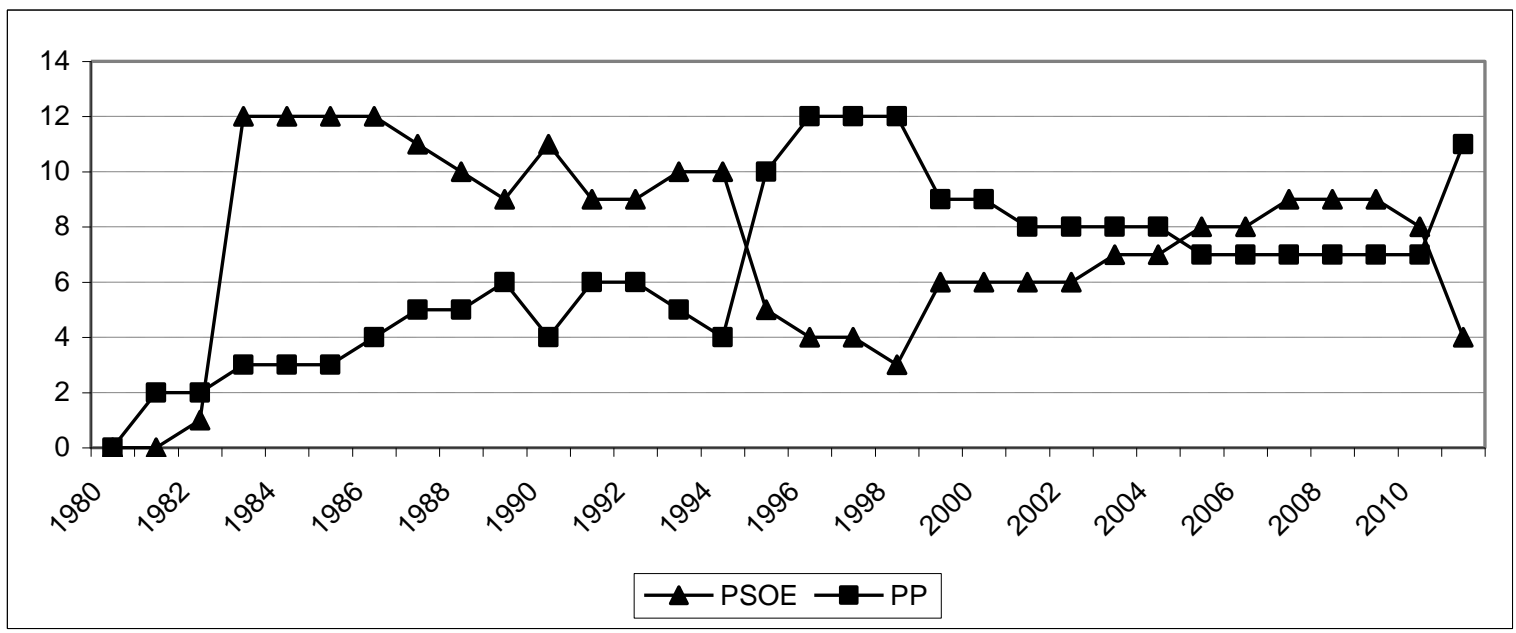

Source: Own elaboration. 
Figure 2. Party position in the two main dimensions of political competition

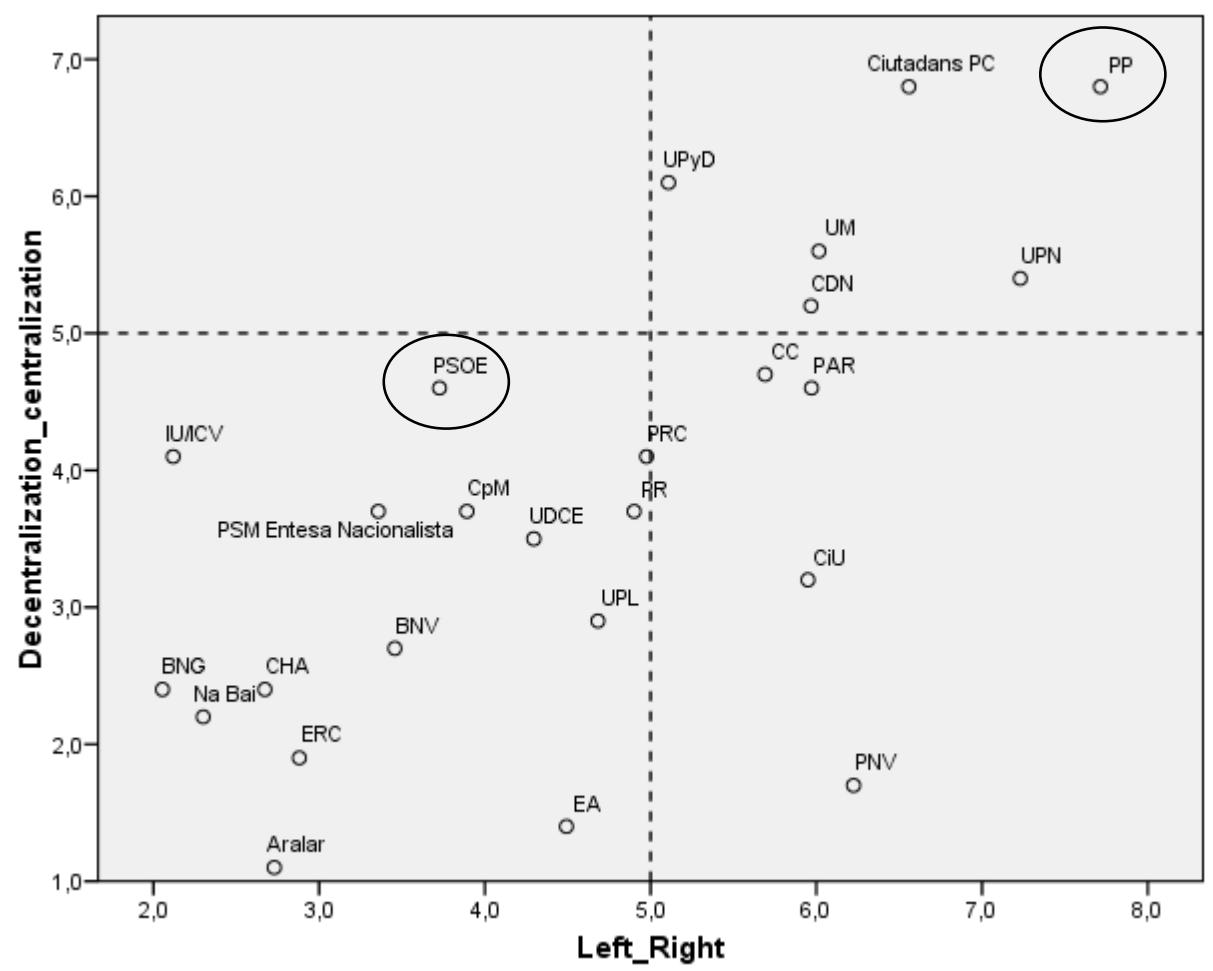

Source: Own elaboration based on CIS study number 2829 (2010). Data reports attributed location of parties by Spanish voters

Ideology: 0 (left) - 10 (right); decentralization: 0 (decentralization) - 10 (centralization).

Acronyms: PSOE (Partido Socialista Obrero Español); PP (Partido Popular); IU/ICV

(Izquierda Unida/Iniciativa per Catalunya Verds); UPyD (Unión Progreso y Democracia); CC

(Coalición Canaria); PAR (Partido Aragonés); CHA (Chunta Aragonesista); $\mathrm{CiU}$

(Convergència i Unió); ERC (Esquerra Republicana de Catalunya); Ciutadans PC (Ciudadanos

- Partido de la Ciudadanía); PNV (Partido Nacionalista Vasco); EA (Eusko Alkartasuna);

Aralar (Aralar); UPN (Unión del Pueblo Navarro); CDN (Convergencia de Demócratas de Navarra); BNG (Bloque Nacionalista Galego); BNV (Bloc Nacionalista Valencià); PSM Entesa

Nacionalista (Partit Socialista de Mallorca/Menorca - Entesa Nacionalista); UM (Unió

Mallorquina); PRC (Partido Regionalista Cántabro); PR (Partido Riojano); UPL (Unión del

Pueblo Leonés); UDCE (Unión Demócrata Ceutî); CpM (Coalición por Melilla). 
Figure 3. Predicted probability of 'support' (linear fit)

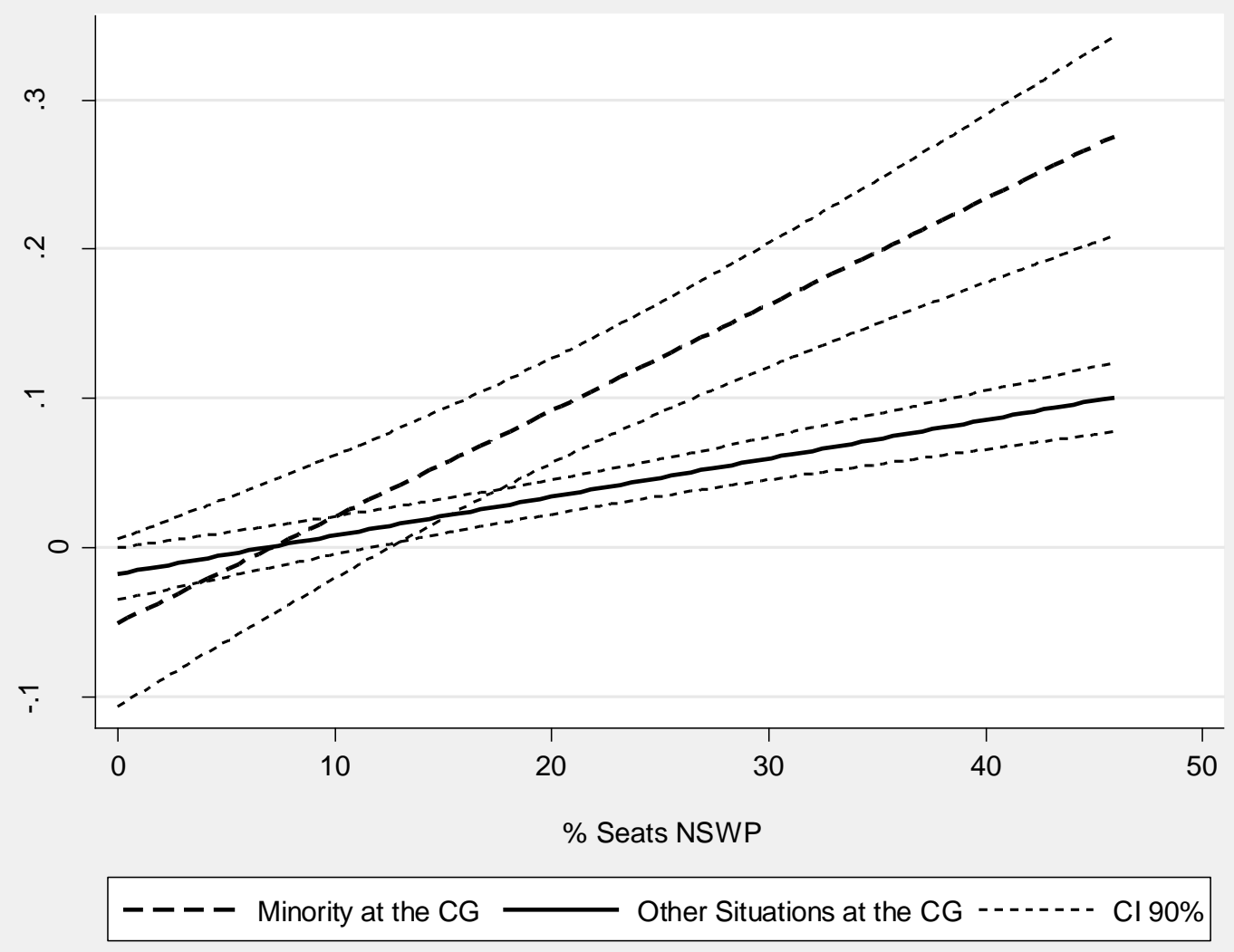

Source: Own elaboration. 